\title{
Three Encounters with Karl W. Deutsch
}

\author{
MIROSLAV HROCH* \\ Charles University, Prague
}

\begin{abstract}
The author approaches the works of Karl W. Deutsch from the position of a historian and presents three aspects of his own encounters with Deutsch's writings. First, he describes how he applied some of the methodological principles in Deutsch's concept of nation-building to his own research work. Second, he presents his opinion on the place Deutsch occupies in the evolution of 'theories of nationalism'. Third, he reflects on how Deutsch's The Nerves of Government can serve as a source of inspiration in the present day, especially the parts of this work that deal with the risks for the collapse of political systems.
\end{abstract}

Keywords: nation, nationalism, history and political science, social communication, Karl W. Deutsch

Sociologický časopis/Czech Sociological Review, 2012, Vol. 48, No. 6: 1115-1129

A historian writing on the work of a scholar specialising in a different field of the social sciences, in this case that of the political scientist Karl W. Deutsch, cannot be expected to engage in a critical analysis of the work itself. The premise of interdisciplinarity is that we approach the results of work in other fields and try to derive methodological and theoretical stimuli therefrom that can be applied to the problems in our own field. On that account, this contribution seeks to reflect on some of Deutsch's thoughts and observations that were and are of use for understanding historical processes in the recent and more distant past, most notably the issue of 'nation-building', and to do so from two angles. First, I will explore how Karl W. Deutsch has helped me to better interpret the process of nationbuilding, and second I will try to determine his place within the context of the development of nationalism theory. However, I also think it useful to draw attention in the third place to the wider significance of his reflections on the stability of political systems. As I intend here to draw mainly on my own experience working in this field, I have adopted the somewhat unorthodox approach of recapitulating my personal 'encounters' with Deutsch's work.

My first encounter began very tangentially: in the mid-1950s I learned that a biography of nationalism compiled by one Karl W. Deutsch had been published in the United States [Deutsch 1956]. It was a smallish brochure-today such a bibliography would be quite thick-and I was disappointed by it in that it

\footnotetext{
* Direct all correspondence to: Miroslav Hroch, Faculty of Humanities, Charles University, U Kř́žze 8, 15800 Prague 5-Jinonice, Czech Republic, e-mail: hrochmir@seznam.cz.
}

(C) Sociologický ústav AV ČR, v.v.i., Praha 2012 
limited itself almost wholly to the present and was dominated by an interest in the term 'nationalism', which I had already come to regard as multivalent and misleading.

Soon after that, sometime around 1960, I came across Deutsch's book Nationalism and Social Communication [Deutsch 1953], which had been published in 1953. I was fascinated by it for at least three reasons. First, because in it Deutsch analysed the processes of nation-building and nationalism sine ira et studio-for him it was a neutral object of investigation, like, for instance, cell division is for a scientist. This approach struck me as the only appropriate one to take, even though in my linguistic consciousness the very term 'nationalism' evoked such negative connotations that I was intent on avoiding it. Second, I was captivated by Deutsch's quantitative approach, which struck me as a very good way of deideologising the actual object of study-national movements and the process of modern nation-building. I was unable (and perhaps even unwilling) to fully understand Deutsch's complicated cybernetic models and equations that, once supplied with the necessary quantitative data, were supposed to be processed by a computer. These equations were, of course, of little use to a historian like me focusing on the 19th century, as there was no way of obtaining the necessary empirical data. Third, I was very pleased to find that Deutsch viewed nationalism not as a contagious idea but as a form of relations between people or between an individual and a large community-the social group of the nation; these relations evolved with the onset of modernisation.

However, I did not then yet appreciate the main and most important thing in Deutsch's work. It would take me several more years spent researching the social and territorial composition of the protagonists of national movements before I did. ${ }^{1}$ One of the basic results of my study was the empirical, quantifiable finding that the roles of active leaders in every national movement were occupied by individuals who had completed the highest level of education that could be attained by any person in their given ethnic group and who held relatively the best jobs that at the given time and in the given country were open to members of the given ethnic group-sometimes this meant a teacher, other times, however, the position of a lawyer. I found that a disproportionately large share of these activists had moved as children from rural areas to urban centres or had grown up in or around an urban centre, or they came from villages in more productive agrarian regions, whose wealthier inhabitants regularly frequented town markets, or they were from regions with a dense network of basic and secondary schools and which regularly produced goods for sale in the markets.

I tried to determine what these characteristics had in common, and as fate would have it I once again reached for Deutsch. I found that he situated the concomitant characteristics of national mobilisation into the wider context of what he termed 'social communication' and 'social mobility'. My empirical findings

${ }^{1}$ Hroch [1968]. 
were in keeping with his hypothesis that the crucial factor behind a person's ability and willingness to adopt a new national identity was a more intense level of involvement in the networks utilised for the dissemination of information, that is, in the system of social communication, which was interlinked with social mobility. After all, for Deutsch, the nation was above all a community arising out of the complementarity of social communication.

Simultaneously I recognised that some empirical data did not corroborate his hypothesis: in many cases, such as Wales and Catalonia, a high level of communication did not automatically lead to strong national mobilisation. I therefore inserted in the conclusion to my book some cautious criticism of the absolute role of communication ties in nation-building processes: they had a mobilising effect only if they were accompanied by sufficiently strong, nationally relevant conflicts [Hroch 1968: 169]. It was moreover around that time, in the late 1960s, that Deutsch himself began to modify his opinions and abandoned his one-sided quantitative approach, and he ceased to regard social communication to be the only key factor in the nation-building process [Deutsch 1969, 1971b]. He also began considering interest conflicts stemming from newly accelerating social mobility. It is telling that in the second edition of Deutsch's book released in 1966 he dropped the appendix that he had included in the first edition, in which he had attempted to empirically demonstrate the validity of his cybernetic models by using statistical data on the Czech-German and Finnish-Swedish situations to predict the future development of the identity of national minorities over the course of the 20th century. According to his calculations, the Swedish minority in Finland and the German minority in Czechoslovakia (had it not been expelled after the war) would be assimilated into the majority population by the 1980s. While the model obviously cannot be verified in the Czech-German case, it can be verified in the Finnish-Swedish case. In the 1960s it was clear that the cybernetic model that predicted the assimilation of the Swedish minority in Finland was not proceeding according to reality.

Were we to regard Deutsch's cybernetic models of assimilation as the most important part of his conception of nation-building processes we would have to put paid to his critics, who rejected his concept of the nation as a product of social communication by deeming it just formalised mechanical quantification. But this view would be misrepresentative. This part of his work is more appropriately seen as the whim of a young researcher smitten by the new research horizons opened up by quantification using cybernetics. Nevertheless, as an error it was a productive one, because it shed light on the limitations to the reliability of cybernetic methods. A more serious question is what role Deutsch's 'communication' theory of nationalism and his concept of the dualism of nation-building and national development played in the advance of research on this issue in the second half of the 20th century.

I asked myself this question a quarter century later upon my second encounter with Deutsch, when, in the late 1990s, I was studying the development 
of 'theories of nationalism', their filiation, or, conversely, their isolated development. ${ }^{2} \mathrm{He}$ occupies a not insignificant place in the context of this development, and this is in no way altered by the fact that many political scientists, like Stein Rokkan, quickly criticised and reproached him for his limited database, for ignoring the effect of political decisions and ideology, and consequently for failing to fully appreciate the role of the subject. ${ }^{3}$ Deutsch and his colleagues (e.g. William J. Foltz, Gabriel Almond, and Lucian Pye) accepted this criticism and revised some of their methods. Nor does it matter that his book was taken into consideration by only a minority of historians in continental Europe, those who had begun to think along interdisciplinary lines.

It is regrettable but characteristic to discover that Deutsch was also ignored by many much younger scholars, who nevertheless started out from similar premises as his (and reached similar conclusions). The word 'ignored' is not altogether accurate: over time some of his methodological principles had become so self-evident for scholars working thirty years or more later that they no longer regarded it necessary even to cite Deutsch as the source of them. Among other scholars, however, it may genuinely have been a matter of ignorance.

It is not the frequency with which he is cited however that determines Deutsch's place in the development of nationalism theory. What matters is that, observed objectively, he was the forerunner on many points. He was the first to intentionally and systematically leave behind the perennialist notions of the nation that dominated up to and through the interwar period and the subjectivist notions that became fashionable after the Second World War, especially under the influence of Hans Kohn. Instead of interpreting the nation and nationalism through the lens of intellectual movements and influences, Deutsch put forward a concept of nation-building ${ }^{4}$ based on objective changes in the sphere of social mobility and communication, which were again the product of modernisation. Anthony D. Smith quite legitimately ranks him first among the classical modernists [Smith 1998: 8], and here it is important to emphasise that he occupies this rank not just for his influence but also because chronologically he came first: he is thus not just a 'classic' but also a 'pioneer' of modernism.

For Deutsch, the nation was indeed unequivocally linked to the process of modernisation, and his term 'nation-building' eventually assumed a life of its own and was used without reference to its original author. This does not mean that this term was generally accepted. Even as Deutsch understood it, the nation

\footnotetext{
2 Some results were summarised under the entry 'Nationalism-Western' in International Encyclopedia of the Social and Behavioral Sciences [Smelser and Baltes 2001].

${ }^{3}$ Deutsch's work has been critiqued by various German historians, such as T. Weiser [1994] and S. Weichlein [2012].

${ }^{4}$ He returned to this terminology in 1966 in the introduction to Nation-Building, which he co-edited with W. J. Foltz [Deutsch and Foltz 1966].

${ }^{5}$ Here, however, Smith wrongly reproaches Deutsch and the 'modernists' for taking too little account of the linguistic (ethnic) background of nation-building.
} 
could not exist without the conscious participation of its members, but national awareness itself was a product of mobilisation, education, and sometimes also political civic engagement. The methods Deutsch used evoked the justifiable impression that he regarded the nation as a mere function of social communication, which from the point of view of a historian is, of course, unacceptable.

Equally unacceptable is the undifferentiating view that identifies linguistic with national assimilation. The above-noted failure of the prediction that the German and Swedish minorities would assimilate in the future was due to the fact that it was based on the erroneous idea that assimilation processes occur somehow 'timelessly', that is, according to the same rules regardless of the stage of evolution that national identity has reached. We cannot apply to the 20th century the patterns that may have applied in the first half of the 19th century, when the majority of the population shared a sense of ethnic affinity, but did not yet identify with a modern nation.

If we allow ourselves not to be deterred by Deutsch's complicated language and confusing cybernetic detours, and if we overlook his one-sided 'communication'-based definition of the nation, we find that Deutsch drew ground-breaking attention to the significant role of various basic factors in the nation-building process, factors that later scholars put forward as their discoveries and that the scholarly community associated with their names, without realising that these 'discoveries' were just newly formulated versions of Deutsch's ideas. Here are some examples.

Frequently cited, whether favourably or critically, is Ernest Gellner's account of the sources of nationalism as lying in processes that he referred to as 'industrialisation' [Gellner 1983: Chapter 3]. However, as far as I know, no one has noticed that the circumstances and context that Gellner applies this term to could equally be referred to as social mobility and communication because they are essentially identical with Deutsch's concept. This is true also of their causal link to the process of modernisation. The difference, of course, is that Gellner's primary category is nationalism as a state of mind or a political concept, while Deutsch's was the nation. What is astonishing is that in the chapter 'Nationalism and Ideology' Gellner explicitly rejects Deutsch's concept of social communication, which he mistakenly interprets as primitive agitation on behalf of the nation [ibid.: Chapter 9]. Conversely, what he counters this with-the all-encompassing presence of the media, regardless of its actual content-was not his invention and rather fully corresponds to the concept put forth by Deutsch. ${ }^{6}$

Benedict Anderson's notion of the nation as an 'imagined community' is rightly identified as a significant step forward and sometimes less rightly even as a turning point in the study of this topic. Leaving aside the fact that many scholars - whether deliberately or out of a misunderstanding — have incorrectly inter-

\footnotetext{
${ }^{6}$ This is moreover not the only instance where Gellner made the target of his criticism an author whose opinion he had interpreted incorrectly.
} 
preted 'imagined' as meaning 'invented', let's look at the actual substance of this concept. Where did the ability of the individual to imagine a plurality of members of his/her nation come from? Anderson himself seeks the historical roots of this ability in book printing -in the coalition between Protestantism and printcapitalism [Anderson 1983: 41], and this certainly apt observation is often cited as Anderson's contribution to the field. However, if we approach these views from a higher level of generalisation we cannot deny the obvious connection to Deutsch's concept of the complementarity of social communication. What else does the capacity for 'imagination' depend upon than the opportunity to obtain information about the outside world, i.e. across social boundaries and settlement perimeters, while the flow of information, which Anderson illustrates in graph form [ibid.: 31], does not depend on a person's changing their place of residence? What else is the educational and mobilising role of book printing than a component of intensifying social communication? Unlike Gellner, Anderson did not consider Deutsch to be even worth a mention or inclusion in his list of references.

The 1990s saw the rise of a new fashion in which the concept of the nation was understood as a 'cultural construct'. If we leave aside the erroneous notion that nations were the product of political manipulation, it must be admitted that this notion was a productive impetus for the view that national identity spread thanks to such cultural activities as commemorating historical anniversaries or figures, monuments, demonstrations, and so forth. An analysis of these activities often tells us how national mobilisation spread, but is less informative about why this happened. Moreover, the role social communication plays in nation-building takes various forms. Deutsch was well aware of the significance of these activities, but he took them to be so self-evident that he did not consider it necessary to address them in greater detail. On the contrary, he was interested in causal connections, which he sought in the context of social changes, which most of the fashionable 'cultural' concepts of nationalism underestimate.

What I mean to demonstrate with these three examples is the fact that in many serious respects Karl W. Deutsch was a forerunner of later research. Many methodological concepts that are presented and celebrated as 'discoveries' are contained in work that Deutsch did several decades before. His fundamental shortcoming was one-sidedly assigning the 'complementarity of social communication' an absolute status as the basic and essentially the only constitutive component in nation-building. Owing to this one-sidedness, Deutsch was relegated by most researchers to the sidelines of nationalism theory and thus marginalised to the edge of oblivion. His later, moreover very interesting, forays into the discussion of nationality issues did very little to alter this. ${ }^{7}$

${ }^{7}$ Cf., for example, 'Nation-Building and National Development', where he explains his concept of nation-building, and which serves as the introduction to Nation-Building [Deutsch and Foltz 1966], or his contribution to the anthology Mobilization, Center-Periphery-Structure and Nation-Building [Torsvik 1981]. 
However, by doing this, these researchers lost out on an important source of information. What makes Deutsch's concept so inspiring even today? Although we shall not share his narrow definition of a nation or inattention to the political and spiritual spheres, we can find a number of methodological approaches in Deutsch that still apply today and a number of observations that are worth mentioning.

It is apt to distinguish first what Deutsch did to so enrich the study of nation-building processes that his innovations came to be taken for granted, and second in what way he can still be a source of inspiration today. The first category includes his ground-breaking approach to situating nation-building processes in the context of the social changes that were occurring on the threshold of the modern era. As already pointed out, Deutsch was a forerunner of modernisation theories of the nation. Most researchers today take it as a given that social mobility and social community played an instrumental role in the spread of national identity and in the success of national movements.

A significant switch was Deutsch's neutral, analytical approach to nationbuilding processes: he is not trying to be a judge or to favour any type of nationbuilding. He also aimed at an approach free from national parochialism, which allowed him to look for more general links. Not a historian, Deutsch could be considered one of the proponents of what is now referred to as transnational history. Although for the most part we no longer share his enthusiasm for mathematical models, there is no question that he was instrumental in winning legitimacy for the use of quantitative methods in the study of particularly the social but also the cultural context of nation-building, phenomena such as literacy, book printing, schools, migration, upward social mobility, the social structure, and so forth.

Some methodological points of inspiration now somewhat forgotten but nonetheless still valid include his observation that nation-building should be examined in the context of continuous processes of assimilation and dissimilation and that national affiliation is not an age-old fact. If we seek to find the sources of national mobilisation, it is necessary to consider the view that social mobility broke down the existing communication structure of agrarian society, and that breakdown gave rise to insecurity and the search for new loyalties, which today we would say culminated in a crisis of identities. Deutsch's terminological distinction between 'people' and 'nation' was never fully appreciated (or even known in the English-language literature). While 'people' is used repeatedly in his writings for a community of individuals who are united by the complementarity of social communication [Deutsch 1953: 75], the term 'nation' already contains the implication of statehood or the struggle for statehood. Only after a 'people' has come into existence may the fight for political power and control of the state commence. With this terminological distinction Deutsch was offering a way out of the misunderstanding arising from the different connotations attached to the English term 'nation' and its Central and Eastern European equivalents (e.g. národ in Czech), which correspond more to the English 'people'. 
Almost unknown now is Deutsch's description of the complementarity of social communication, which he saw as how the members of a nation (people) are able to communicate across the boundaries of social institutions and groups more effectively with each other, within the group, than they can with others on the outside [ibid.: 71]. This feature is largely ignored now, although its application in historical research remains essential today.

My third encounter with Karl W. Deutsch occurred under altogether different circumstances. At the end of 1968, when I was a guest docent in Freiburg (Breisgau), a group of local postgraduate students and tutors-historians and political scientists - obtained a copy of Deutsch's recently published The Nerves of Government and decided to organise a regular seminar to discuss his ideas. They were primarily interested in discovering to what extent his theoretical conclusions on political systems and changing forms of government could be used not just to understand historical processes but also to look for solutions to the contemporary situation, which they saw to be a deep systemic crisis in capitalism. I no longer remember what conclusions they reached, I just recall their opinion that Deutsch is extremely useful as a methodological starting point, but not as a manual for political action. Perhaps even more momentous was that I took away from my reading of Deutsch on that occasion the finding that political science is a scientific field that is theoretical, intellectually complex, and above all independent of political ideologies and party sympathies and interests.

Deutsch's book was also published in Czech, but it had no opportunity to have any significant impact given that at the onset of the Normalisation period in the 1970s it was withdrawn from library circulation and the remaining copies were in all likelihood destroyed. ${ }^{8}$ I don't know whether this is the answer to why The Nerves of Government has made so little mark on contemporary Czech political science. A recently published introduction to political science contains only four references to his name, two of them in my chapter on theories of nationalism, and there is no reference to The Nerves of Government at all. ${ }^{9}$ Perhaps this has to do with the fact that Deutsch's analysis of problems involves a higher level of abstraction than what is customary in Czech political science circles.

I picked up this book again when I was invited to contribute to this special section on Karl Deutsch. The thoughts he expresses in the final chapters (most notably 'The Self-Closure of Political Systems') particularly intrigued me-not as a political scientist, but as a citizen aware of the difficulties and problems confronting the world today. And perhaps also as a historian trying to understand the flow of history and crises in systems in a context wider than just lamentations about corruption or squabbles over balanced budgets.

\footnotetext{
${ }^{8}$ Neroy vlády [1971a].

9 See Miroslav Novák [2012]. Yet, at the start of the 1990s Deutsch's book was still recommended as reading for an introduction to the study of, not political science, but rather sociology. See E. Urbánek and J. Buriánek, Základy sociologie [1991].
} 
The analyses therein discuss the different aspects of what the author refers to as 'autonomy' in the sense of the self-steering ability of the state or other organisations [Deutsch 1966: 219]. It is worth noting that the book was written in the first half of the $1960 \mathrm{~s}^{10}$ when two alternative systems of state organisation existed-from the various versions of socialism through to right-wing dictatorships-and when their future development was still open. His thoughts about which mechanisms of self-steering might pose a threat to the existing system or by contrast strengthen its chances for survival therefore seemed very relevant then.

While today the alternatives of development look very different, reading Deutsch nonetheless helps us to better understand even the (seemingly) 'alternative-less' present in Fukuyama's 'end of history' world. He helps us to realise that the roots of the problems in today's world lie much deeper than what Fukuyama concedes and than what contemporary political science tells us. It is not my intention here to analyse Deutsch's book in full, but I shall zero in on several thoughtprovoking observations. Taken as a whole they may seem inconsistent, but they point to general connections and phenomena that, if we reflect on them, can help us to make more qualified considerations about the crises and conflicts of our age. His interpretations are also demonstrative proof that standing outside the sphere dominated by party struggles does not mean to be unengaged.

A frequent objection to Deutsch's theories, of course, is that they are an expression of his one-sided fascination with cybernetics and his naive belief that social processes can be explained and perhaps even steered by computer technology. We shall see, however, that these reproaches are only partly justified, as Deutsch, despite his fascination with the potential of computer methods, also took into account the factor of individual decision making, which can be classed as an ethical-philosophical coordinate, as an equal component in his analysis.

I'll start with Deutsch's general-sounding assertion that states should not be evaluated on the basis of their ability to function as states, i.e. according to their ability to maintain stable power relations and a certain degree of economic equilibrium. What is key is to evaluate states based on the scope of opportunities they offer their citizens for personal development, which does not mean prosperity or financial gain, but personal qualities, moral integrity, and education levels. In order for this to function, however, the state system must be secured. Deutsch embraces the view that feedback is essential for securing the system's functioning and that it is a fatal mistake to underestimate how important this is. As an example he cites how failing to allow for feedback opens the door to popular discontent, social conflicts, or even panic in the market in response to uncontrolled inflation [Deutsch 1966: 191].

By contrast, the significance of individual politicians should not be overestimated, nor should it be believed that simply changing the people in office can bring about a change in the system: 'Social settings may produce new officeholders

${ }^{10}$ The first edition, which is not the one usually cited, dates from 1963. 
very similar to former incumbents.' What is more important, therefore, is to map the centres of decision-making and decision-making systems [Deutsch 1966: 211].

In Deutsch's thoughts about the 'self-closure of political systems', feedback is a key factor of 'autonomy' (self-steering). Every system, and thus also state, is steered 'by a loop sequence of decisions that feeds back upon itself'. A precondition of success, however, is that a self-steering system disposes of enough information from the present and the past about itself and its goals [ibid. 219].

If every government is inundated on a daily basis with enormous amounts of information, it has to pick out what is important. There is a risk that when doing so it will prioritise unrepresentative, unessential pieces of information over information that is fundamentally important simply because it is ideologically biased, and this bias makes such inconsequential information seem more interesting and therefore also better. This biased selection of information makes consciousness a 'false consciousness' and leaves governments operating according to 'their own impression of their own actions', and such impressions can be the diametric opposite to what the government is doing in reality.

This can become a factor of risk simply because the autonomy of a decision-making system is by its nature variable. For this reason it is important that the changes a government makes be functional ones. The success or failure of the system's continued functioning depends on whether these changes are viable or, conversely, dysfunctional. Dysfunctional decisions give rise to failures and even to the risk of the system breaking down [ibid.: 221].

Deutsch distinguishes six situations, more specifically, six types of changes, that can lead to the breakdown of the system. I would venture to say that each of them is a factor that can weaken systems even today.

(1) 'The failure of power' results from policies that cause the loss or enervation of material and social resources necessary to sustain power. This includes, for instance, wastage, profligate economic policy, the destruction of natural resources, and the prioritisation of quick profit at the expense of long-term development. A shared feature of such mistakes is that precedence is given to current interests over future ones. And as part of this, educational institutions are neglected: it is forgotten that man is a factor of future growth [ibid.: 223].

(2) 'The gradual narrowing of intake of information' from already existing channels of information from the outside world. From there it proceeds that internal information begins to take precedence over external information, so priority is given to information drawn from memory, and information is accepted regardless of how consequential it is. The system then has a tendency to confine itself within an invisible rut of routine. Ethnocentric tendencies are a part of this and result from the predominance of contacts within the national community in connection with intense communication: as a consequence of this, relevant information about things abroad and the opinions or deeds of other nations are ignored. All of this may occur unconsciously and need not assume the character of aggressive nationalism [ibid.: 224]. 
(3) 'The loss of steering capacity or coordination.' This happens when an autonomous system becomes more complex, and the length of the channels through which information must flow before it turns into a decision grows longer and internal communication and coordination of actions slows down. As a consequence of growth, organisations have a tendency to react more slowly, which they then make up for with abrupt, erroneous decisions [ibid.: 225].

(4) 'The loss of depth of memory' or the loss of coordination between behaviour and memory: old data are retrieved, but little data get in from the outside. Communication between memory and action degenerates as a consequence of the fact that the process whereby information is spread is improperly connected to decision-making on further actions.

(5) 'The loss of the capacity for partial inner rearrangement' occurs when too much value is placed on established routines for producing and recombining data. As a consequence, thought is prevailingly shallow, there is a progressive intellectual decline, and the system becomes exhausted. A possible way out is a new internal rearrangement of memory, and an emphasis on new combinations.

(6) 'The loss of the capacity for structural rearrangement' takes place when the system becomes exhausted, and it is manifested in the degeneration of self-steering mechanisms. This is accompanied by an attempt in the subjective sphere to avoid engagement, apathy, and then withdrawing into a shell [ibid.: 227].

Deutsch sees the factors that cause the system to fail as lying in the objective consequences of 'changes in the configuration of communication channels', and also with individuals. He therefore recommends looking for principles that can maintain the stability of autonomous systems in the long term.

At this point in his reflections, Deutsch steps outside himself and reaches for a change in paradigm. He notes that maintaining the stability of the system must be contemplated not just in the categories of communication theory but also in generally human categories: it is necessary to take account of the fact that the role of the individual should not be overlooked in the process of self-steering. Politics is not just a matter of power, but also of human qualities-and thus of education and morality. So he decided to shift his point of view and enrich his analysis by contemplating the relationship of humans to the processes of 'self-steering' and the human role in them in a context defined by a pair of concepts drawn from the sphere of ethics and religion.

The first concept is 'humility', which is set in opposition to the 'sin of pride'. Although Deutsch does not explicitly define 'pride', it is apparent from the context that he understands it as synonymous with some of the factors that contribute to the failure of systems, such as favouring what is close over what is far away, the familiar over the new, the present over the future. On an ethical level this threat can be countered with the 'command of humility', by which Deutsch means a favourable, open attitude to facts and information that do not directly affect the 
subject, that is, 'an openness to experience and to criticism, sensitivity and the ability to respond to the needs of others'. So there is a political significance to not placing too much value on one's own importance, experience, and problems, and to adopting a positive attitude towards new ideas, which, to use the language of cybernetics, entails both trying to maintain and expand the channels for receiving external information and a willingness for internal rearrangement. This also means the 'willingness to be humble in the face of experimental fact, and to respect the work of others' [ibid.: 230]. In Deutsch's view, sensitivity towards the opinions of others is more important than trying to do good for others based on one's own exclusive ideas about what is right. This is where the 'sin of pride', the very opposite of all the positive attitudes of humility, manifests itself [ibid.: 229].

'Lukewarmness' is how Deutsch describes the refusal of commitment, which in his eyes is a variety of self-centredness and self-overestimation. The opposite of this is 'faith', signifying commitment. Faith differs from conviction, which refuses to consider any alternatives, because it acknowledges objective difficulties in the assertion of its own proposition or project, but for that very reason regards it as essential to become committed to the project in which faith is placed. Deutsch sees a relationship of mutual tension between faith and humility: faith is about commitment in support of one's own opinions, but humility cautions us not to trust our judgement. He considers the combination of faith and humility a precondition for the long-term survival of the system, and by this he means being able to combine the capacity of enthusiasm for new projects with openness to alternative information and the ability to change the arrangement of the system [ibid.: 232].

The next pair of opposites is 'reverence' and 'idolatry'. Reverence is understood to be the demand to attach greater value to external and new information, that is, information about things that do not directly pertain to us (not-us) and that are larger than we are or have their own patterns of existence and behaviour. Deutsch labels as idolatry the attitude that favours the familiar over the infinite, the local over the general, which elevates the familiar and the local to the level of absolute values. It is idolatrous 'to worship the letter above the spirit', to honour traditional law over human rights, and to give priority to established interests over human needs. Here he is making reference to Toynbee's 'idolisation of ephemeral institutions'.

Deutsch interprets 'love' as the opposite of two phenomena, one of which he calls 'cosmopolitanism' and the other 'nationalism'. He believes that the need for equilibrium between these two is expressed in the commandment 'Thou shalt love thy neighbour as thyself'. This is certainly a contentious recommendation, but it is a fruitful starting point for discussion.

In theory, cosmopolitanism and nationalism are not incompatible with love: '... no individual, no culture, no people can endure without self-respect and without placing a positive value on its own memories and its own character' [ibid.: 234]. On the other hand, no one should place their own preferences over and above experiences and information from the outside. In practice, however, 
we know there is a 'horizontal' exclusiveness to certain (cosmopolitan) elitist groups, and the 'vertical' exclusiveness of nationalism is vociferously expressed. Both these forms of exclusiveness taken to the extreme are at odds with love. Love for thy neighbour should be ranked on the same level as love for thy country. Love signifies respect and self-respect, openness to needs of any kind, willingness for positive engagement.

However, this kind of equilibrium is 'almost unattainable', and most people give priority to the problems in their immediate environment (the family, community, country). This is where Deutsch sees the danger of 'blindness, idolatry, and lukewarmness' to the needs and interests of others who are farther away. If these attitudes then prevail on a general level, there looms a pessimistic scenario where it will be impossible to maintain equilibrium between the opposites of cosmopolitanism and nationalism, and thereby also maintain a truly autonomous system or, as the case may be, political organisation.

Some might deem these theories trivial or old-fashioned, but if we consider them in conjunction with the factors that threaten the autonomy (self-steering) and consequently the very existence of systems they assume a timeless significance and serve as a warning even for our times.

As already stated, it is not the purpose of these lines to offer an exhaustive analysis of Deutsch's views, but rather to draw attention to the contemporary relevance of his ideas on the maintenance of systems bound to the autonomy (or self-steering) of communication mechanisms. It remains to add that in Deutsch's theory of systems as a whole, self-steering makes up the fourth of the six 'dimensions of growth', while growth together with adaptability and the capacity to learn represent the essentials for the survival of societies and cultures. Unlike the simplified perspective commonly applied today where the growth of society is reduced to economic growth, Deutsch regards the latter as just one of six dimensions of growth [ibid.: 250].

The first of these dimensions is labour force growth, the second economic growth, the third is the availability of work and human resources. The fifth dimension that he regards as an element of autonomy is what he calls 'strategic simplifications', which is about the ability of the system to manage its growth and the associated surfeit of information by being able to alter its communication patterns so as to simplify communication to just its key components. The sixth dimension is the ability to change goals in the process of long-term growth, which means the ability for politicians to learn and to create a social environment geared towards initiative and creativity.

In all these processes, politics is the originator of decisions that it can assert and that can thus be an instrument of either the acceleration or, equally, the deceleration of 'social learning and innovation'. Over the last pages of the book Deutsch finally applies his interpretation to actual political systems. He cites as the key 'techniques for accelerating innovations' that strengthen the system three principles asserted in 'Western' politics: majority government, the protection of 
minorities, and the institutionalisation of dissent. In his view these three techniques are what have enabled Western governments and political systems to secure the resources and tools for rapid social learning and innovation [ibid.: 254].

Deutsch does not then posit on this basis that other systems should adopt Western institutions as the ideal model, but he believes that 'non-Western' systems will have to develop mechanisms that will allow them to function as mechanisms of social learning 'by which mankind in its various subdivisions, still organized in states, can adapt more quickly to the dangerous but hopeful tasks of growing up' [ibid.: 256].

If we stopped at just a superficial reading of these conclusions we might observe that Deutsch arrived at a naively optimistic vision of the convergent development of the world. Subjectively he may have been genuinely convinced of this. But from an objective and retrospective point of view, his analysis contains, without even trying, a very persuasive account of the causes of the weakness of the Soviet system of 'really existing socialism' and, implicitly, a prognosis of its demise. Expressed in his terms: no system can survive in the long term if it is undermined on a continuous and systematic basis because its self-steering underestimated feedback and neglected information from the outside world, a system in which, again in Deutsch's words, pride prevails over humility, lukewarmness over faith, and idolatry over reverence. I believe that this methodological approach offers a way of interpreting the causes of the 'collapse of communism' that could produce persuasive findings rather than some prevalent myths.

It remains to ask to what extent Deutsch's model of the demise of a system could serve as a warning for Europe and the current 'Western' world. Perhaps we could apply what Deutsch says in the first chapter of his book about the development of science to the development of society. Namely, that there is an alternation between empirical and philosophical ages, and empirical ages, however successful they are, always end in the need for a revision of basic concepts because they are no longer suited to the guiding strategies worked out during the previous philosophical age. Perhaps a new 'philosophical crisis', as Deutsch called it, is approaching, 'an age of re-examination of concepts, methods, interests, of a search for new symbolic models and new strategies' [ibid.: 4]. Now, a half century later, are Deutsch's premonitions about the possibilities of change not becoming a realistic necessity?

Translated by Robin Cassling

Miroslav Hroch (1932) is a Czech historian and political scientist with a particular interest in the comparative history of nationalism. He is professor emeritus of general history at Charles University in Prague. His works include The Social Preconditions of National Revival in Europe (1985, 2000), In the National Interest (2000), and Národy nejsou dílem náhody (Nations Aren't the Work of Chance, 2009). 


\section{References}

Anderson, B. 1983. Imagined Communities. Reflections on the Origin and Spread of Nationalism. London: Verso.

Deutsch, K. W. 1953. Nationalism and Social Communication. Cambridge, MA: MIT.

Deutsch, K. W. 1956. Interdisciplinary Bibliography on Nationalism. Cambridge, MA: Technology Press of MIT.

Deutsch, K. W. 1966. The Nerves of Government. Models of Political Communication and Control. New York: The Free Press.

Deutsch, K. W. 1969. Nationalism and Its Alternatives. New York: Random House.

Deutsch, K. W. 1971a. Nervy vlády. Prague: Svoboda.

Deutsch, K. W. 1971b. 'Social Mobilization and Political Development.' American Political Science Review 65: 493-514.

Deutsch, K. W. and W. J. Foltz (eds.). 1966. Nation-Building. New York: Atherton Press.

Gellner, E. 1983. Nations and Nationalism. Oxford: Blackwell.

Hroch, M. 1968. Die Vorkämpfer der nationalen Bewegung bei den kleinen Völkern Europas. Prague: Univerzita Karlova.

Novák, Miroslav. 2012. Úvod do studia politiky (Introduction to the Study of Politics) Prague: Sociologické nakladatelství.

Smelser, N. J. and P. B. Baltes. 2001. International Encyclopedia of the Social and Behavioral Sciences. Amsterdam: Elsevier.

Smith, A. D. 1998. Nationalism and Modernism. London and New York: Routledge.

Torsvik, P. (ed.) 1981. Mobilization, Center-Periphery-Structure and Nation-Building. Bergen: Universitets Forlag.

Urbánek, E. and J. Buriánek. 1991. Základy sociologie. (The Basics of Sociology) Prague: $S \& M$.

Weichlein, S. 2012. 'Soziale Kommunikation: K. W. Deutsch und die Folgen.' Pp. 36-38 in Historische Nationsforcschung im geteilten Europea 1945-1989, edited by P. Kolár and M. Řezník. Cologne: SH Verlag.

Weiser, T. 1994. 'K. W. Deutschs Modell der Nationswerdung.' Pp. 130-138 in Formen des nationalen Bewustseins im Lichte zeitgenössischer Nationalismustheorien, edited by E. Schmidt-Hartmann. Munich: R. Oldenbourg Verlag. 